\title{
Interactive comment on "OSL rock surface exposure dating as a novel approach for reconstructing transport histories of coastal boulders over decadal to centennial timescales" by Dominik Brill et al.
}

\section{Dominik Brill et al.}

brilld@uni-koeln.de

Received and published: 14 October 2020

We appreciate the constructive comments and suggestions on our manuscript. For our deteiled reply to each of them please see the attached supplementary file.

Please also note the supplement to this comment: 
Interactive comment on Earth Surf. Dynam. Discuss., https://doi.org/10.5194/esurf-2020-46, 2020.

\section{ESurfD}

Interactive comment 